\title{
Changes in photosynthetic and chlorophyll fluorescence characteristics of sorghum under drought and waterlogging stress
}

\author{
F. ZHANG ${ }^{* * * *}$, K. ZHU $^{* *}$, Y.Q. WANG ${ }^{* *}$, Z.P. ZHANG ${ }^{* *}$, F. LU**, H.Q. YU ${ }^{*++}$, and J.Q. ZOU*,+ \\ Agronomy Courtyard, Shenyang Agricultural University, Dongling Road 120, Shenhe District, Shenyang, \\ 110866 Liaoning, China* \\ Sorghum Institute, Liaoning Academy of Agricultural Sciences, Dongling Road 84, Shenyang, 110161 Liaoning, \\ China $^{* *}$
}

\begin{abstract}
Water stress is a key factor limiting sorghum growth and yield potential. This study investigated the changes in morphology, photosynthetic parameters, and fluorescence characteristics of sorghum under drought and waterlogging stress. The results indicated that these two types of water stress limited sorghum growth and led to a decrease in leaf chlorophyll (Chl), especially $\mathrm{Chl} a$, which was accompanied by a decrease in net photosynthetic rate. In addition, under both types of water stress, the light-compensation point (LCP) and light-saturation point (LSP) both decreased, but the effect on these parameters was more obvious under drought. In terms of fluorescence parameters, the initial fluorescence and variable fluorescence increased under drought and waterlogging stress, while the maximum fluorescence did not change significantly, and the electron transport rate, photochemical quenching, and PSII actual quantum yield decreased. In summary, these results suggest that sorghum adapts to drought and waterlogging stress by reducing the leaf Chl $a$ content, reducing LCP and LSP, and changing fluorescence parameters.
\end{abstract}

Additional key words: drought stress; excessive soil moisture; gas exchange; photosynthesis; Sorghum bicolor.

\section{Introduction}

With global climate change, the shortage of freshwater resources and the imbalanced distribution of water are becoming more serious each year, and water stress has become the main factor limiting global agricultural production (Tambussi et al. 2005, Khan et al. 2016). Furthermore, because of the variation in precipitation in recent years, the area of land suffering from water stress is gradually increasing (Kataria et al. 2015, Wang et al. 2019a). Water stress may arise as a result of waterlogging or water deficit (Guo et al. 2018). For example, sorghum (Sorghum bicolor L. Moench), which is grown in Northern China, where water resources are often limited, is subjected to drought stress early during the growing season in the spring. During the wet summer season, however, sorghum may suffer intermittent or long-term waterlogging stress (Liu et al. 2009).
It has been reported that the production of photosynthetic material plays an important role in crop growth and yield formation, and that the production of biomass and the physiological characteristics of crops are greatly affected by water stress (Wang et al. 2019a). Extensive studies have shown changes in anatomical and morphological features, such as root architecture, leaf area, and plant height under water stress (Wang et al. 2004, Radhakrishnan et al. 2012). Moreover, excessive soil moisture (EM) has been shown to reduce stomatal conductance $\left(g_{\mathrm{s}}\right)$, transpiration $(E)$, photosynthetic rate $\left(P_{\mathrm{N}}\right)$, and other physiological parameters of dry land crops such as corn (Zea mays L.) (Zaidi et al. 2003) and winter wheat (Triticum aestivum L.) (Abid et al. 2018). Many researchers have pointed out that water stress can cause leaf stomatal closure and decrease intercellular $\mathrm{CO}_{2}$ concentration $\left(C_{\mathrm{i}}\right)$, available $\mathrm{CO}_{2}$ concentration in mesophyll cells, and carbon assimilation (Zou et al. 2019). This is due to a decline in photosynthetic rate

\footnotetext{
Received 15 June 2019, accepted 2 October 2019.

+Corresponding author; e-mail: yuhaiqiu@syau.edu.cn (H.Q. Yu), jianqiuzou@126.com (J.Q Zou)

Abbreviations: $\mathrm{Chl}$ - chlorophyll; $C_{\mathrm{i}}$ - intercellular $\mathrm{CO}_{2}$ concentration; DS - drought stress; $E$ - transpiration rate; EM - excessive soil moisture; ETR - electron transfer rate; $\mathrm{F}_{0}$ - minimal fluorescence yield of the dark-adapted state; $\mathrm{F}_{0}{ }^{\prime}-$ minimal fluorescence yield of the light-adapted state; $\mathrm{F}_{\mathrm{m}}$ - maximal fluorescence yield of the dark-adapted state; $\mathrm{F}_{\mathrm{m}}{ }^{\prime}$ - maximum fluorescence yield; $\mathrm{F}_{\mathrm{v}}$ - variable fluorescence; $\mathrm{F}_{\mathrm{v}} / \mathrm{F}_{0}$ - variable fluorescence out of minimal fluorescence yield under the dark-adapted state; $F_{v} / F_{m}-$ maximal quantum yield of PSII photochemistry; $g_{\mathrm{s}}$ - stomatal conductance; LCP - light-compensation point; LSP - light-saturation point; $\mathrm{NPQ}$ - nonphotochemical quenching; OD - optical density; $P_{\mathrm{N}}$ - net photosynthetic rate; $\mathrm{q}_{\mathrm{P}}$ - photochemical quenching coefficient; RWC - relative water content; WUE - water-use efficiency; $\mathrm{Y}_{(\mathrm{NO})}$ - nonregulated energy dissipation of electron yield; $\mathrm{Y}_{(\mathrm{NPQ})}-$ quantum energy output under light adaptation; $\Phi_{\mathrm{PSII}}$ - actual photochemical efficiency.

Acknowledgments: Financial assistance was received from the Sorghum Research and Development Program, Ministry of Agriculture of the People's Republic of China (CARS-06-13.5-A11, CARS-06-13.5-A11, A22), and the Liaoning Provincial Natural Science Foundation Project, China (2019-MS-197).
} 
and a reduction in biomass accumulation (Gomes-Laranjo et al. 2006). Studies have also indicated that adaptive changes in the $\mathrm{Chl}$ fluorescence of crops could enhance crop resilience to water stress (Rahbarian et al. 2011).

Sorghum, which has resistance to both drought and EM stress, has become the first choice for crop production in water-stressed production systems around the world (O'Shaughnessy et al. 2012, Kadam et al. 2017). It has better adaptability to water stress than corn, wheat, and cotton (Houx and Fritschi 2013), and is widely planted in arid and semiarid regions (Li et al. 2017). At the same time, due to the aerated structure of its root tissue cell system, sorghum has good adaptability to overexposed plots and is suitable for planting in low-lying plots with an uneven water distribution (Viator et al. 2010). However, sorghum still exhibits changes in morphology and photosynthetic physiology in order to regulate metabolism (Wang et al. $2019 b$ ). In the case of water deficit and excessive water stress, changes in the morphology and physiology of plants also improve resistance to water stress (Vandoorne et al. 2012).

We studied how the resistance to water stress in sorghum is achieved through changes in morphology, photosynthetic parameters, fluorescence characteristics, and photosystem response under drought and waterlogging stress in order to further promote the resistance of sorghum production under water stress.

\section{Materials and methods}

Study site: This research was conducted in a mobile shelter at the Agricultural Research Center, Liaoning Academy of Agricultural Sciences in Shenyang, China $\left(38.47^{\circ} \mathrm{N}\right.$, $120.28^{\circ} \mathrm{W}$ ), which is located in a temperate semihumid continental climate zone in the southeastern part of China. The average daily temperature was $24.7^{\circ} \mathrm{C}$ during the spring and summer of the study (May to October 2018), and the average day/night temperature difference was $12.3^{\circ} \mathrm{C}$

Experimental material: The test material was sorghum (Sorghum bicolor L. Moench cv. Ba YQ), which was selected based on the results of a previous test of the response of 16 sorghum cultivars to drought and excessive water stress. Sorghum (cv. Ba YQ) is representative of the 16 tested cultivars in aspects of the response to water stress.

Experimental setting: The experiments were performed from May to October in 2018. Sorghum (cv. Ba YQ) seeds were planted in pots with a diameter of $40 \mathrm{~cm}$ and a depth of $35 \mathrm{~cm}$. In order to reduce the impact of the external environment, all pots were buried in the soil, with the top edge of the pot flushed with the ground. Each pot was filled with $7.5 \mathrm{~kg}$ of sieved air-dried loam soil. The soil contained $0.115 \%$ total $\mathrm{N}, 0.158 \%$ total $\mathrm{P}, 2.157 \%$ total $\mathrm{K}$, $72 \mathrm{mg}$ (available N) $\mathrm{kg}^{-1}, 17.1 \mathrm{mg}$ (available P) $\mathrm{kg}^{-1}$, and $138 \mathrm{mg}$ (available $\mathrm{K}) \mathrm{kg}^{-1}$, with $\mathrm{pH}$ of 6.8. Fertilizer, $20 \mathrm{~g}$ of $\left(\mathrm{NH}_{4}\right)_{2} \mathrm{HPO}_{4}$ per pot, was applied when the sorghum was planted, and $50 \mathrm{~g}$ of $\mathrm{CO}\left(\mathrm{NH}_{2}\right)_{2}$ per pot was applied at
8 weeks after emergence. The experiment was performed in a complete randomized block design with three replicates. There were six pots in each repeat, with a total of 54 pots.

Moisture treatment: Three treatments were applied: (1) excess moisture (EM; soil water content of 35-40\%); (2) normal water supply (control; soil water content 25-30\%); and (3) drought stress (DS; soil water content of $15-20 \%$ ). Each pot was equipped with a moisture sensor, and soil moisture was monitored using a realtime monitoring and adjustment system (D500, Shenzhen Libituo Technology Co., Ltd., China). The sensor probe was placed at a depth of $20 \mathrm{~cm}$ below the mouth of the pot because this is the area in which the root system was mainly distributed. Once every hour the soil moisture was measured, and water was supplemented. In addition, the soil moisture was verified using the weighing method every day at 17:00 $\mathrm{h}$ to ensure that the moisture-monitoring system was working properly.

Measurement period: Previous water stress experiments with 16 sorghum varieties showed that the period from the sorghum growing point differentiation stage to the booting stage occurred from 25 to $50 \mathrm{~d}$ after sowing. During this period, sorghum was the most sensitive to soil moisture and water stress had the greatest influence on the growth and yield. Therefore, water stress treatment was applied in two stages: at 25 and $50 \mathrm{~d}$ after sowing continuously for $15 \mathrm{~d}$ for each treatment. Immediately after the stress, agronomic traits, photosynthetic parameters, and Chl fluorescence were determined.

Agronomic traits: Five plants from each treatment (EM, control, and DS) were selected for the measurement of agronomic traits. Plant height was determined prior to harvesting by measuring the distance from the base to the highest point of the plant. The stem diameter at the middle of the fifth internode of the plant was measured using an electronic vernier caliper. The green leaf area was measured using a leaf area scanner $(Y M J-B$, Zhejiang Top Instruments Co., Ltd., China). Five plants per soil treatment were cut at the ground level, then cut subsequently into three segments: stalks, grain, and leaves along with sheaths. Yields of fresh stalks and grain as well as leaves and sheaths were measured with an electronic scale. After determining the fresh mass (FM), each sample was divided into two equal parts. One portion was dried at $105^{\circ} \mathrm{C}$ for half an hour and then dried at $70^{\circ} \mathrm{C}$ for $48 \mathrm{~h}$ to achieve constant mass. The dry mass (DM) of the root, leaf, and stem was then determined. The second portion was immersed in deionized water for $12 \mathrm{~h}$ and the turgid mass (TM) was measured. The relative water content (RWC) was then calculated using the following equation: $\mathrm{RWC}[\%]=(\mathrm{FM}-\mathrm{DM}) /(\mathrm{TM}-\mathrm{DM}) \times 100$.

Chl content: The leaf $\mathrm{Chl}$ content was determined using the ethanol-acetone method (Zhang 1992). Sorghum leaves $(0.1 \mathrm{~g})$ were cut out with scissors, placed in a $25-\mathrm{ml}$ test tube, and $10 \mathrm{ml}$ of ethanol-acetone mixture was added. The mixture was sealed with a rubber stopper and then 
placed in darkness for $24 \mathrm{~h}$. The optical density (OD) values at wavelengths 470,645 , and $663 \mathrm{~nm}$ were measured using a spectrophotometer $(D-8 P C$, Phile Instrument Co., $L t d$., China), and the $\mathrm{Chl} a$, Chl $b$, and Chl $(a+b)$ contents were calculated as follows: Chl $a=12.72 \mathrm{D}_{663}-2.81 \mathrm{D}_{645}$, Chl $b=2013 \mathrm{D}_{645}-5.03 \mathrm{D}_{663}$, where $\mathrm{D}_{645}$ and $\mathrm{D}_{663}$ represent the OD values of the leaf pigment extract at 645 and $663 \mathrm{~nm}$, respectively, Chl $(a+b)=\mathrm{Chl} a+\mathrm{Chl} b$.

Photosynthetic parameters: Photosynthesis and lightresponse curves of the leaves were measured using a LI-6400 portable photosynthetic analyzer (LI-COR, Lincoln, NE, USA). Measurements were taken on sunny days from 9:00 to 11:00 h. Five sorghum plants of consistent growth were selected from each water stress condition, and the net photosynthetic rate $\left(P_{\mathrm{N}}\right)$, intercellular $\mathrm{CO}_{2}$ concentration $\left(C_{\mathrm{i}}\right)$, stomatal conductance $\left(g_{\mathrm{s}}\right)$, and transpiration rate $(E)$ of the uppermost fully developed leaf were determined. The intensity of the built-in red and blue light source (LI-6400-02BLED) was 1,000 $\mu \mathrm{mol}$ (photon) $\mathrm{m}^{-2} \mathrm{~s}^{-1}$, the instrument leaf chamber temperature was $25^{\circ} \mathrm{C}$, the air relative humidity was $60 \%$, and the leaf chamber $\mathrm{CO}_{2}$ flow rate was $400 \mu \mathrm{mol} \mathrm{s}^{-1}$.

When measuring the light-response curve, the intensity of the built-in red and blue light source (LI-6400-02B $L E D)$ was set to range from strong to weak intensity, and the PPFD was sequentially set to 1,$800 ; 1,600 ; 1,400$; 1,$200 ; 1,000 ; 800,600,400,200,100,80,60,40,20,10$, and $0 \mu \mathrm{mol}$ (photon) $\mathrm{m}^{-2} \mathrm{~s}^{-1}$. The photosynthesis lightresponse curve $\left(P_{\mathrm{N}}-\right.$ PPFD curve) was plotted with PPFD on the horizontal axis and the $P_{\mathrm{N}}$ on the vertical axis. The $P_{\mathrm{N}}$-PPFD curve was fitted with Data Processing System version 7.05 (DPS7.05) (Xu et al. 2014a). The maximum photosynthetic rate $\left(P_{\mathrm{N} \max }\right)$, apparent quantum efficiency $(\alpha)$, and dark respiration rate $\left(R_{\mathrm{d}}\right)$ were obtained, and the light-compensation point (LCP), light-saturation point (LSP), and leaf water-use efficiency (WUE) were calculated as follows: WUE $[\%]=P_{\mathrm{N}} / E \times 100, \mathrm{LCP}=$ $\left(P_{\mathrm{Nmax}} R_{\mathrm{d}}\right) /\left[\alpha\left(P_{\mathrm{N} \max }-R_{\mathrm{d}}\right)\right], \mathrm{LSP}=\left[P_{\mathrm{N} \max }\left(0.75 P_{\mathrm{N} \max }+R_{\mathrm{d}}\right)\right] /$ $\left[\alpha\left(0.25 P_{\text {Nmax }}-R_{\mathrm{d}}\right)\right]$. LSP was estimated assuming PAR with a $P_{\mathrm{N}}$ of $75 \%$ of the $P_{\mathrm{Nmax}}$ (Zhou et al. 2014).

The Chl fluorescence parameters $F_{m}{ }^{\prime}, q_{P}, N P Q, \Phi_{P S I I}$, $\mathrm{Y}_{(\mathrm{NPQ})}, \mathrm{Y}_{(\mathrm{NO})}$, and ETR were determined using a portable Chl fluorescence instrument (PAM-2500, Walz, Germany). The fully expanded leaf at the top of the plant (the $16^{\text {th }}$ leaf from the root) was used for measurements. A darkadaptation clamp specially made by Walz (Germany) was used to fully adapt the blade for more than half an hour, and then the leaf in the dark was measured. Corresponding parameters under dark adaptation conditions, $\mathrm{F}_{0}, \mathrm{~F}_{\mathrm{m}}, \mathrm{F}_{\mathrm{v}} / \mathrm{F}_{\mathrm{m}}$, were measured. Then the dark-adapted leaves were treated with actinic light, of the light intensity gradient ranging from weak to strong intensity $[0,1,2,31,64,101,198$, 363, 619, 981; 1,386; and 1,663 $\mu \mathrm{mol}$ (photon) $\mathrm{m}^{-2} \mathrm{~s}^{-1}$, and with an action time of $30 \mathrm{~s}$. The $\mathrm{q}_{\mathrm{P}}, \mathrm{NPQ}, \Phi_{\mathrm{PSII}}, \mathrm{Y}_{(\mathrm{NPQ})}$, $\mathrm{Y}_{(\mathrm{NO})}$, and ETR of the modulated energy dissipation were then measured.

Statistical analysis: All measurements were carried out three times per moisture treatment (one time per replicate), and there were three plants per replicate. Analysis of variance (ANOVA) was performed using $S A S$ software (SAS Institute, NC, USA) and the significance of main effects was determined using Duncan's multiple range test $(P<0.05)$.

\section{Results}

Agronomic parameters: Compared with the control, sorghum plant height and green leaf area were lower under water deficit, but slightly higher under EM; there was little difference in stem diameter between the three water treatments (Table 1). Plant height and green leaf area decreased significantly both at 25 and $50 \mathrm{~d}$ after water treatments. The interaction between different measurement times (DT) and water treatment $(\mathrm{WT})(\mathrm{WT} \times \mathrm{DT})$ also differed. In addition, there was a significant effect of WT on RWC, with the highest RWC observed in the leaf followed by the root and the stem.

Table 1. Changes in agronomic parameters of sorghum under water stress treatments applied at 25 and $50 \mathrm{~d}$ after sowing. Data represent means $\pm \mathrm{SD}, n=5$. Different lowercase letters indicate significant differences according to Duncan's multiple range test $(P<0.05)$. ** - significant difference at the 0.01 level, ${ }^{*}$ - significant difference at the 0.05 level, ns - difference is not significant. DT - days after treatment, WT - water treatment, RWC - relative water content.

\begin{tabular}{|c|c|c|c|c|c|c|c|}
\hline Time $[\mathrm{d}]$ & Treatment & Plant height $[\mathrm{cm}]$ & Stem diameter $[\mathrm{mm}]$ & $\begin{array}{l}\text { Green leaf area } \\
{\left[\mathrm{cm}^{2} \text { per plant }\right]}\end{array}$ & $\begin{array}{l}\text { RWC [\%] } \\
\text { Root }\end{array}$ & Leaf & Stem \\
\hline \multirow[t]{3}{*}{25} & Control & $117.3 \pm 3.2^{b}$ & $132.5 \pm 4.2^{\mathrm{a}}$ & $1534.9 \pm 25.8^{\mathrm{b}}$ & $78.9 \pm 1.7^{\mathrm{a}}$ & $83.5 \pm 2.6^{\mathrm{a}}$ & $73.6 \pm 1.8^{\mathrm{a}}$ \\
\hline & Waterlogging stress & $120.6 \pm 2.7^{\mathrm{a}}$ & $133.4 \pm 3.5^{\mathrm{a}}$ & $1755.4 \pm 19.7^{\mathrm{a}}$ & $75.2 \pm 2.3^{\mathrm{b}}$ & $79.0 \pm 3.5^{\mathrm{b}}$ & $69.1 \pm 3.4^{\mathrm{b}}$ \\
\hline & Drought stress & $106.6 \pm 4.6^{c}$ & $112.3 \pm 3.1^{\mathrm{b}}$ & $1215.6 \pm 33.8^{c}$ & $63.4 \pm 0.8^{c}$ & $68.7 \pm 3.2^{c}$ & $57.8 \pm 3.7^{\mathrm{c}}$ \\
\hline \multirow[t]{3}{*}{50} & Control & $141.1 \pm 2.1^{\mathrm{a}}$ & $153.2 \pm 2.9^{\mathrm{a}}$ & $2356.3 \pm 22.4^{\mathrm{a}}$ & $75.3 \pm 3.9^{\mathrm{a}}$ & $80.4 \pm 2.4^{\mathrm{a}}$ & $69.3 \pm 2.5^{\mathrm{a}}$ \\
\hline & Waterlogging stress & $143.0 \pm 3.8^{\mathrm{a}}$ & $155.6 \pm 4.1^{\mathrm{a}}$ & $2082.5 \pm 34.9^{b}$ & $63.7 \pm 2.3^{\mathrm{b}}$ & $71.3 \pm 1.9^{\mathrm{b}}$ & $63.6 \pm 2.3^{\mathrm{b}}$ \\
\hline & Drought stress & $132.1 \pm 2.9^{\mathrm{b}}$ & $145.3 \pm 3.6^{\mathrm{b}}$ & $1568.7 \pm 41.3^{c}$ & $45.4 \pm 1.7^{\mathrm{c}}$ & $49.8 \pm 0.7^{\mathrm{c}}$ & $61.1 \pm 1.6^{\mathrm{b}}$ \\
\hline \multicolumn{2}{|c|}{ WT ( $F$ value $)$} & $17.5^{*}$ & $23.3^{*}$ & $45.4^{* *}$ & $94.7^{* *}$ & $104.5^{* *}$ & $8.7^{\mathrm{ns}}$ \\
\hline \multicolumn{2}{|c|}{ DT ( $F$ value $)$} & $85.3^{* *}$ & $59.7^{* *}$ & $124.3^{* *}$ & $24.4^{*}$ & $42.5^{*}$ & $11.3^{\mathrm{ns}}$ \\
\hline \multicolumn{2}{|c|}{$\mathrm{WT} \times \mathrm{DT}(F$ value $)$} & $21.9^{*}$ & $18.1^{*}$ & $87.4^{* *}$ & $41.2^{* *}$ & $7.4^{\mathrm{ns}}$ & $10.9^{\mathrm{ns}}$ \\
\hline
\end{tabular}


This result can be more intuitively observed in Fig. 1; the change in the leaf color in response to water-deficit treatment was clearly visible. There was also a difference in aerial root production: 17 aerial roots were produced under EM treatment, four aerial roots were produced under normal water conditions, and no aerial roots were produced under DS (Fig. 1).

Chl content: After water stress treatment, the leaf Chl $a$, Chl $b$, and Chl $(a+b)$ contents decreased compared with those of the control, and the decrease in Chl $a$ was significantly higher than that of Chl $b$ (Fig. 2). After the waterlogging and drought treatments applied $25 \mathrm{~d}$ after sowing, the differences in $\mathrm{Chl} b$ content under stress were not significant, while the differences in $\mathrm{Chl}(a+b)$ and $\mathrm{Chl} a$ content were extremely significant. This result indicated that Chl $a$ was more affected by stress applied at $25 \mathrm{~d}$ than that of Chl $b$. After EM treatment or DS applied at $50 \mathrm{~d}$, the leaf Chl $(a+b), \mathrm{Chl} a$, and $\mathrm{Chl} b$ contents were significantly different from those of the control. In addition, for both the treatments at 25 and $50 \mathrm{~d}$, the leaf Chl $(a+b), \mathrm{Chl} a$, and $\mathrm{Chl} b$ contents under DS were an order of magnitude higher than those under the EM treatment. This indicated that water stress, especially DS, decreased Chl biosynthesis, which led to the accelerated decomposition of Chl. The reduction of Chl content in sorghum leaves after water stress treatment may prevent the absorption of excess light energy and damage of photosynthetic apparatus.

Photosynthetic parameters: After EM and DS treatment, $P_{\mathrm{N}}$ decreased significantly compared with the control, and this decrease was higher under DS (Table 2). A similar trend was observed for $g_{\mathrm{s}}, E$, and WUE, while the change in $C_{\mathrm{i}}$ was significantly negatively correlated with $P_{\mathrm{N}}$. In addition, the effects of WT $\times$ DT interaction were also generally different. Taken together, these results indicated that water stress, especially the duration of stress, had an adverse effect on the photosynthesis of sorghum plants, but sorghum plants could enhance resistance to water stress through the regulation of photosynthetic parameters such as $g_{\mathrm{s}}, E$, and WUE.

Under water stress, the LCP and LSP of sorghum decreased, but only LCP was significantly different between different water treatments. The difference in LSP was not significant; especially the decrease in DS was more pronounced (Table 3 ). In addition, there were significant WT $\times$ DT interaction effects. The changes in $P_{\text {Nmax }}, \alpha$, and $R_{\mathrm{d}}$ values showed that water stress, especially DS, could decrease the LCP and affect the production of photosynthetic materials.

Chl fluorescence: After the $25 \mathrm{~d}$ of stress treatments, the $\mathrm{F}_{0}$
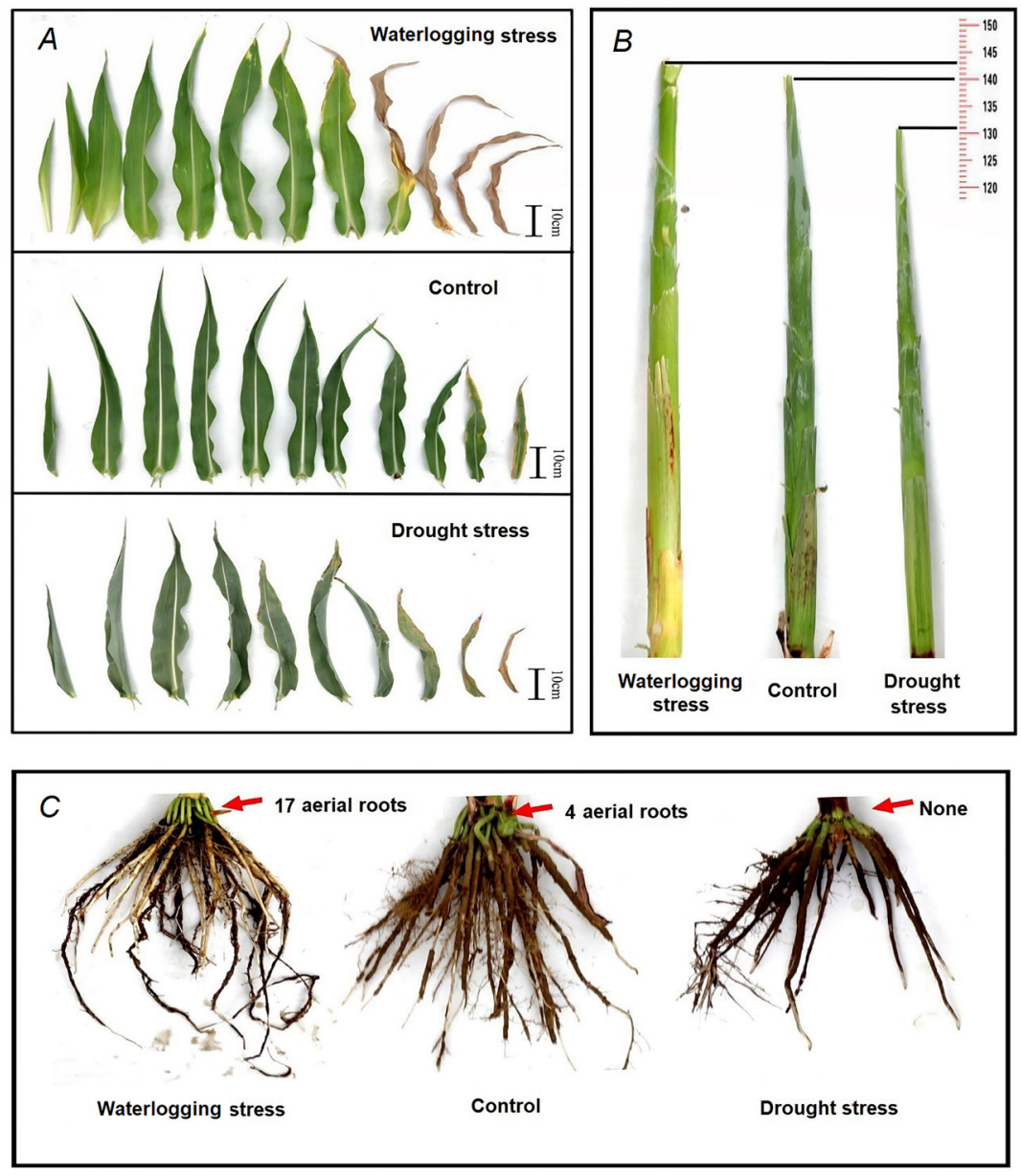

Fig. 1. Comparison of phenotypes of sorghum after treatment with different water stresses initiated at $50 \mathrm{~d}$ after sowing. $(A),(B)$, and $(C)$ panels show leaf, stem, and root, respectively. 


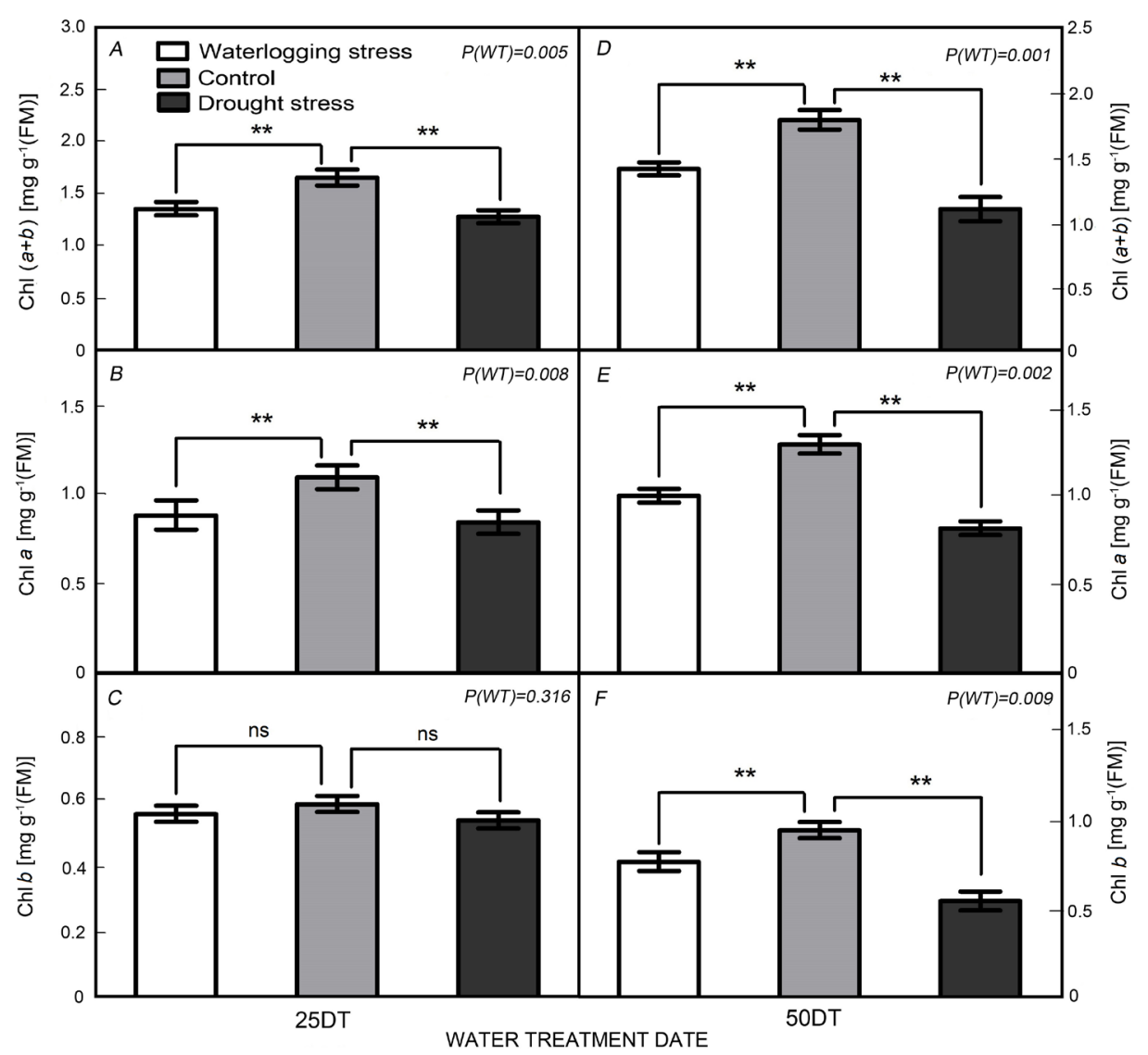

Fig. 2. Changes in leaf chlorophyll (Chl) $(a+b)$, Chl $a$, and Chl $b$ contents in sorghum under water stress treatments applied at 25 and $50 \mathrm{~d}$ after sowing. $P$ (WT) refers to the significant difference between different soil moisture treatments. ** - significant difference at the 0.01 level, ${ }^{*}$ - significant difference at the 0.05 level, ns - difference is not significant. The error bars show SE, $n=5$. DT - days after treatment, WT - water treatment, RWC - relative water content.

Table 2. Photosynthetic parameters of sorghum leaves under water stress treatments applied at 25 and $50 \mathrm{~d}$ after sowing. Data represent means $\pm \mathrm{SD}(n=5)$. Different lowercase letters indicate significant differences according to Duncan's multiple range test $(P<0.05)$. ${ }^{* *}$ - significant difference at the 0.01 level, ${ }^{*}$ - significant difference at the 0.05 level, ns - difference is not significant. $P_{\mathrm{N}}-$ net photosynthetic rate, $g_{\mathrm{s}}$ - stomatal conductance, $E$ - transpiration rate, $C_{\mathrm{i}}-$ intercellular $\mathrm{CO}_{2}$ concentration, WT - water treatment, DT - days after treatment.

\begin{tabular}{|c|c|c|c|c|c|c|}
\hline $\begin{array}{l}\text { Time } \\
\text { [d] }\end{array}$ & Treatment & $\begin{array}{l}P_{\mathrm{N}} \\
{\left[\mu \mathrm{mol} \mathrm{m}{ }^{-2} \mathrm{~s}^{-1}\right]}\end{array}$ & $\begin{array}{l}g_{\mathrm{s}} \\
{\left[\mathrm{mol}\left(\mathrm{H}_{2} \mathrm{O}\right) \cdot \mathrm{m}^{-2} \mathrm{~s}^{-1}\right]}\end{array}$ & $\begin{array}{l}C_{\mathrm{i}} \\
{\left[\mu \mathrm{mol}\left(\mathrm{CO}_{2}\right) \cdot \mathrm{m}^{-2} \cdot \mathrm{s}^{-1}\right]}\end{array}$ & $\begin{array}{l}E \\
{\left[\mathrm{mmol}\left(\mathrm{H}_{2} \mathrm{O}\right) \mathrm{m}^{-2} \cdot \mathrm{s}^{-1}\right]}\end{array}$ & $\begin{array}{l}\text { WUE } \\
{\left[\mathrm{mol}\left(\mathrm{CO}_{2}\right) \cdot \operatorname{mol}\left(\mathrm{H}_{2} \mathrm{O}\right)^{-1}\right]}\end{array}$ \\
\hline \multirow[t]{3}{*}{25} & Control & $24.60 \pm 0.6^{\mathrm{a}}$ & $0.39 \pm 0.05^{\mathrm{a}}$ & $268.35 \pm 19.26^{\mathrm{c}}$ & $4.19 \pm 0.21^{\mathrm{a}}$ & $5.87 \pm 0.35^{\mathrm{a}}$ \\
\hline & Waterlogging stress & $20.91 \pm 0.9^{b}$ & $0.31 \pm 0.07^{b}$ & $302.92 \pm 20.23^{b}$ & $3.86 \pm 0.14^{b}$ & $5.41 \pm 0.33^{\mathrm{b}}$ \\
\hline & Drought stress & $17.55 \pm 1.1^{\mathrm{c}}$ & $0.27 \pm 0.04^{\mathrm{c}}$ & $358.72 \pm 13.18^{\mathrm{a}}$ & $3.54 \pm 0.09^{\mathrm{c}}$ & $4.94 \pm 0.21^{\mathrm{c}}$ \\
\hline \multirow[t]{3}{*}{50} & Control & $27.74 \pm 1.8^{\mathrm{a}}$ & $0.43 \pm 0.05^{\mathrm{a}}$ & $241.74 \pm 24.21^{\mathrm{c}}$ & $4.61 \pm 0.29^{\mathrm{a}}$ & $6.01 \pm 0.48^{\mathrm{a}}$ \\
\hline & Waterlogging stress & $20.41 \pm 0.8^{\mathrm{b}}$ & $0.32 \pm 0.06^{\mathrm{b}}$ & $294.02 \pm 17.84^{b}$ & $3.66 \pm 0.13^{b}$ & $5.57 \pm 0.27^{b}$ \\
\hline & Drought stress & $14.82 \pm 1.2^{\mathrm{c}}$ & $0.17 \pm 0.05^{\mathrm{c}}$ & $391.40 \pm 11.29^{\mathrm{a}}$ & $2.89 \pm 0.12^{\mathrm{c}}$ & $5.12 \pm 0.19^{c}$ \\
\hline \multicolumn{2}{|c|}{ WT ( $F$ value $)$} & $118.7^{* *}$ & $154.8^{* *}$ & $32.1^{*}$ & $85.7^{* *}$ & $59.6^{* *}$ \\
\hline \multicolumn{2}{|c|}{ DT ( $F$ value $)$} & $24.2^{*}$ & $18.4^{*}$ & $4.9^{\mathrm{ns}}$ & $28.9^{*}$ & $24.8^{*}$ \\
\hline \multicolumn{2}{|c|}{$\mathrm{WT} \times \mathrm{DT}(F$ value $)$} & $32.5^{*}$ & $5.3^{\mathrm{ns}}$ & $15.8^{*}$ & $27.2^{*}$ & $29.8^{*}$ \\
\hline
\end{tabular}

and $\mathrm{F}_{\mathrm{v}}$ increased significantly, but there was no significant change in the $\mathrm{F}_{\mathrm{m}}$. However, after the end of the $50 \mathrm{~d}$ of water stress treatments, these fluorescence parameters increased (Table 4). This indicated that the water stress treatments significantly enhanced the photochemical activity and damaged the PSII reaction center; the decrease in $F_{v} / F_{m}$ after the $50 \mathrm{~d}$ of water stress treatments further illustrates this point.
Photoresponse of the photosynthetic apparatus: After water stress treatment, the ETR, $\mathrm{q}_{\mathrm{P}}$, and PSII actual quantum yield ( $\left.\mathrm{Y}_{(\mathrm{II})}\right)$ decreased, and NPQ increased (Fig. 3). The decrease in $\mathrm{q}_{\mathrm{P}}$ indicates that the proportion of open PSII reaction centers decreased and that the potential activity of PSII decreased. The increase in NPQ indicates that the potential heat dissipation capacity of PSII was enhanced and that excess light energy was consumed by NPQ, which 
Table 3. Changes in light-compensation point (LCP), light-saturation point (LSP), and related parameters of sorghum leaves under water stress applied at 25 and $50 \mathrm{~d}$ after sowing. ${ }^{* *}$ - significant difference at the 0.01 level, ${ }^{*}$ - significant difference at the 0.05 level, ns - difference is not significant. $P_{\mathrm{Nmax}}-$ estimated maximum net photosynthesis, $\alpha$-apparent quantum efficiency, $R_{\mathrm{d}}-$ apparent dark respiration rate, $\mathrm{WT}$ - water treatment, DT - days after treatment.

\begin{tabular}{|c|c|c|c|c|c|c|c|}
\hline $\begin{array}{l}\text { Time } \\
\text { [d] }\end{array}$ & Treatment & $\begin{array}{l}\mathrm{LCP} \\
{[\mu \mathrm{mol} \text { (photon) }} \\
\left.\mathrm{m}^{-2} \mathrm{~s}^{-1}\right]\end{array}$ & $\begin{array}{l}\text { LSP } \\
{[\mu \mathrm{mol}(\text { photon) }} \\
\left.\mathrm{m}^{-2} \cdot \mathrm{s}^{-1}\right]\end{array}$ & $\begin{array}{l}P_{\mathrm{N} \max } \\
{\left[\mu \mathrm{mol}\left(\mathrm{CO}_{2}\right)\right.} \\
\left.\mathrm{m}^{-2} \mathrm{~s}^{-1}\right]\end{array}$ & $\begin{array}{l}\alpha \\
{\left[\mu \mathrm{mol}\left(\mathrm{CO}_{2}\right)\right.} \\
\left.\mathrm{m}^{-2} \mathrm{~s}^{-1}\right]\end{array}$ & $\begin{array}{l}R_{\mathrm{d}} \\
{\left[\mu \mathrm{mol}\left(\mathrm{CO}_{2}\right)\right.} \\
\left.\mathrm{m}^{-2} \mathrm{~s}^{-1}\right]\end{array}$ & $R^{2}$ \\
\hline \multirow[t]{3}{*}{25} & Control & $51.8 \pm 2.9^{\mathrm{a}}$ & $2829.2 \pm 29.6^{\mathrm{a}}$ & $24.71 \pm 0.06^{\mathrm{a}}$ & $0.055 \pm 0.003^{\mathrm{b}}$ & $2.6 \pm 0.3^{\mathrm{a}}$ & $0.98 \pm 0.05^{\mathrm{a}}$ \\
\hline & Waterlogging stress & $39.1 \pm 2.1^{\mathrm{b}}$ & $2458.6 \pm 65.7^{\mathrm{b}}$ & $20.38 \pm 0.13^{b}$ & $0.059 \pm 0.007^{\mathrm{a}}$ & $2.1 \pm 0.2^{\mathrm{b}}$ & $0.95 \pm 0.02^{\mathrm{a}}$ \\
\hline & Drought stress & $36.4 \pm 1.2^{\mathrm{b}}$ & $2016.8 \pm 45.3^{\mathrm{c}}$ & $17.82 \pm 0.08^{\mathrm{c}}$ & $0.052 \pm 0.004^{\mathrm{c}}$ & $1.9 \pm 0.1^{\mathrm{b}}$ & $0.96 \pm 0.06^{\mathrm{a}}$ \\
\hline \multirow[t]{3}{*}{50} & Control & $52.1 \pm 2.4^{\mathrm{a}}$ & $2882.1 \pm 89.7^{\mathrm{a}}$ & $27.93 \pm 0.09^{\mathrm{a}}$ & $0.057 \pm 0.006^{\mathrm{a}}$ & $2.6 \pm 0.3^{\mathrm{a}}$ & $0.93 \pm 0.02^{\mathrm{a}}$ \\
\hline & Waterlogging stress & $36.8 \pm 3.6^{\mathrm{b}}$ & $2440.9 \pm 72.9^{b}$ & $20.68 \pm 0.11^{\mathrm{b}}$ & $0.056 \pm 0.005^{\mathrm{a}}$ & $2.1 \pm 0.1^{\mathrm{b}}$ & $0.95 \pm 0.07^{\mathrm{a}}$ \\
\hline & Drought stress & $30.2 \pm 1.4^{\mathrm{c}}$ & $1978.8 \pm 59.3^{\mathrm{c}}$ & $14.79 \pm 0.05^{\mathrm{c}}$ & $0.049 \pm 0.003^{\mathrm{b}}$ & $1.8 \pm 0.3^{\mathrm{c}}$ & $0.97 \pm 0.04^{\mathrm{a}}$ \\
\hline \multicolumn{2}{|c|}{ WT ( $F$ value) } & $145.4^{* *}$ & $8.7^{\mathrm{ns}}$ & $121.8^{* *}$ & $18.9^{*}$ & $24.6^{*}$ & $4.1^{\mathrm{ns}}$ \\
\hline \multicolumn{2}{|c|}{ DT ( $F$ value $)$} & $17.5^{*}$ & $12.3^{*}$ & $18.2^{*}$ & $3.8^{\mathrm{ns}}$ & $7.4^{\mathrm{ns}}$ & $5.8^{\mathrm{ns}}$ \\
\hline \multicolumn{2}{|c|}{$\mathrm{WT} \times \mathrm{DT}(F$ value $)$} & $22.3^{*}$ & $12.8^{*}$ & $12.4^{*}$ & $3.5^{\mathrm{ns}}$ & $4.2^{\mathrm{ns}}$ & $11.1^{*}$ \\
\hline
\end{tabular}

Table 4. Changes in chlorophyll fluorescence parameters of sorghum under water stress applied at 25 and $50 \mathrm{~d}$ after sowing. Data represent means $\pm \mathrm{SD}, n=5$. Different lowercase letters indicate significant differences according to Duncan's multiple range test $(P<0.05) .{ }^{* *}$ - significant difference at the 0.01 level, ${ }^{*}$ - significant difference at the 0.05 level, ns - difference is not significant. WT water treatment, DT - days after treatment, $\mathrm{F}_{0}$ - minimal fluorescence yield of the dark-adapted state, $\mathrm{F}_{\mathrm{m}}$ - maximal fluorescence yield of the dark-adapted state, $\mathrm{F}_{\mathrm{v}}$ - variable fluorescence, $\mathrm{F}_{\mathrm{v}} / \mathrm{F}_{0}$ - variable fluorescence out of minimal fluorescence yield under dark-adapted state, $\mathrm{F}_{\mathrm{v}} / \mathrm{F}_{\mathrm{m}}$ - maximal quantum yield of PSII photochemistry.

\begin{tabular}{lllllll}
\hline Time $[\mathrm{d}]$ & Treatment & $\mathrm{F}_{0}$ & $\mathrm{~F}_{\mathrm{m}}$ & $\mathrm{F}_{\mathrm{v}}$ & $\mathrm{F}_{\mathrm{v}} / \mathrm{F}_{0}$ & $\mathrm{~F}_{\mathrm{v}} / \mathrm{F}_{\mathrm{m}}$ \\
\hline 25 & Control & $0.24 \pm 0.03^{\mathrm{c}}$ & $1.08 \pm 0.05^{\mathrm{a}}$ & $0.84 \pm 0.09^{\mathrm{a}}$ & $3.50 \pm 0.21^{\mathrm{a}}$ & $0.78 \pm 0.07^{\mathrm{a}}$ \\
& Waterlogging stress & $0.26 \pm 0.06^{\mathrm{b}}$ & $1.06 \pm 0.03^{\mathrm{ab}}$ & $0.80 \pm 0.03^{\mathrm{b}}$ & $3.08 \pm 0.18^{\mathrm{b}}$ & $0.75 \pm 0.05^{\mathrm{ab}}$ \\
& Drought stress & $0.29 \pm 0.02^{\mathrm{a}}$ & $1.03 \pm 0.05^{\mathrm{b}}$ & $0.74 \pm 0.06^{\mathrm{c}}$ & $2.55 \pm 0.12^{\mathrm{c}}$ & $0.72 \pm 0.06^{\mathrm{b}}$ \\
$50 \quad$ Control & $0.23 \pm 0.03^{\mathrm{c}}$ & $1.07 \pm 0.02^{\mathrm{c}}$ & $0.84 \pm 0.05^{\mathrm{b}}$ & $3.65 \pm 0.23^{\mathrm{a}}$ & $0.79 \pm 0.05^{\mathrm{a}}$ \\
& Waterlogging stress & $0.25 \pm 0.01^{\mathrm{b}}$ & $1.10 \pm 0.07^{\mathrm{bc}}$ & $0.85 \pm 0.06^{\mathrm{b}}$ & $3.40 \pm 0.09^{\mathrm{b}}$ & $0.77 \pm 0.07^{\mathrm{ab}}$ \\
& Drought stress & $0.30 \pm 0.04^{\mathrm{a}}$ & $1.18 \pm 0.03^{\mathrm{a}}$ & $0.88 \pm 0.04^{\mathrm{a}}$ & $2.93 \pm 1.25^{\mathrm{c}}$ & $0.75 \pm 0.04^{\mathrm{b}}$ \\
WT $(F$ value $)$ & $25.3^{*}$ & $5.8^{\mathrm{ns}}$ & $21.2^{*}$ & $35.8^{*}$ & $7.5^{\mathrm{ns}}$ \\
DT $(F$ value $)$ & $4.1^{\mathrm{ns}}$ & $1.3^{\mathrm{ns}}$ & $12.4^{*}$ & $8.5^{\mathrm{ns}}$ & $5.7^{\mathrm{ns}}$ \\
WT $\times$ DT $(F$ value $)$ & $4.2^{\mathrm{ns}}$ & $3.8^{\mathrm{ns}}$ & $11.4^{\mathrm{ns}}$ & $25.8^{*}$ & $2.1^{\mathrm{ns}}$ \\
\hline
\end{tabular}

dissipates energy, preventing or mitigating damage to the photosynthetic mechanism caused by excessive absorption of light energy by PSII. After water stress treatment, ETR and $Y_{(I I)}$ were lower than that under normal conditions, indicating that water-stress treatment reduced the actual photosynthetic capacity, the proportion of photochemical reaction, and the photosynthetic ETR.

\section{Discussion}

Previous studies have shown that water stress can significantly inhibit the vegetative growth of crops (Downie et al. 2004). The present study revealed that when sorghum was subjected to water stress, plant height and green leaf area were lower under water-deficit conditions, but slightly higher under excessive moisture stress. This is consistent with the previous finding that when the soil moisture was excessive, there were differences in inhibition of plant height and leaf growth (Ullah et al. 2018). We also found that aerial roots grew abundantly under EM stress, but that no new aerial roots were found under DS. This indicates that under EM stress, the metabolic balance of sorghum can be maintained by increasing the number of aerial roots, and that under DS, water metabolism is mainly regulated through a reduction of water loss and curling of the leaves. This may be an important cause of the differences in plant height between the water deficit and EM treatments. Such studies have demonstrated similarities in crops, such as canola (Brassica napus L.) and sunflower (Helianthus annuus L.) (Sun et al. 2010). In addition, it has also been found that under water stress, the metabolism of crops is disrupted and plant growth is restricted (Waraich et al. 2011, Shao et al. 2016), which may also explain the changes in morphology during water stress.

$\mathrm{Chl}$, the main photosynthetic pigment in plant leaves, is an important indicator used for evaluating the physiological status of plants; it is also an important indicator reflecting the photosynthetic capacity of leaves (Xu et al. 2014b). In 


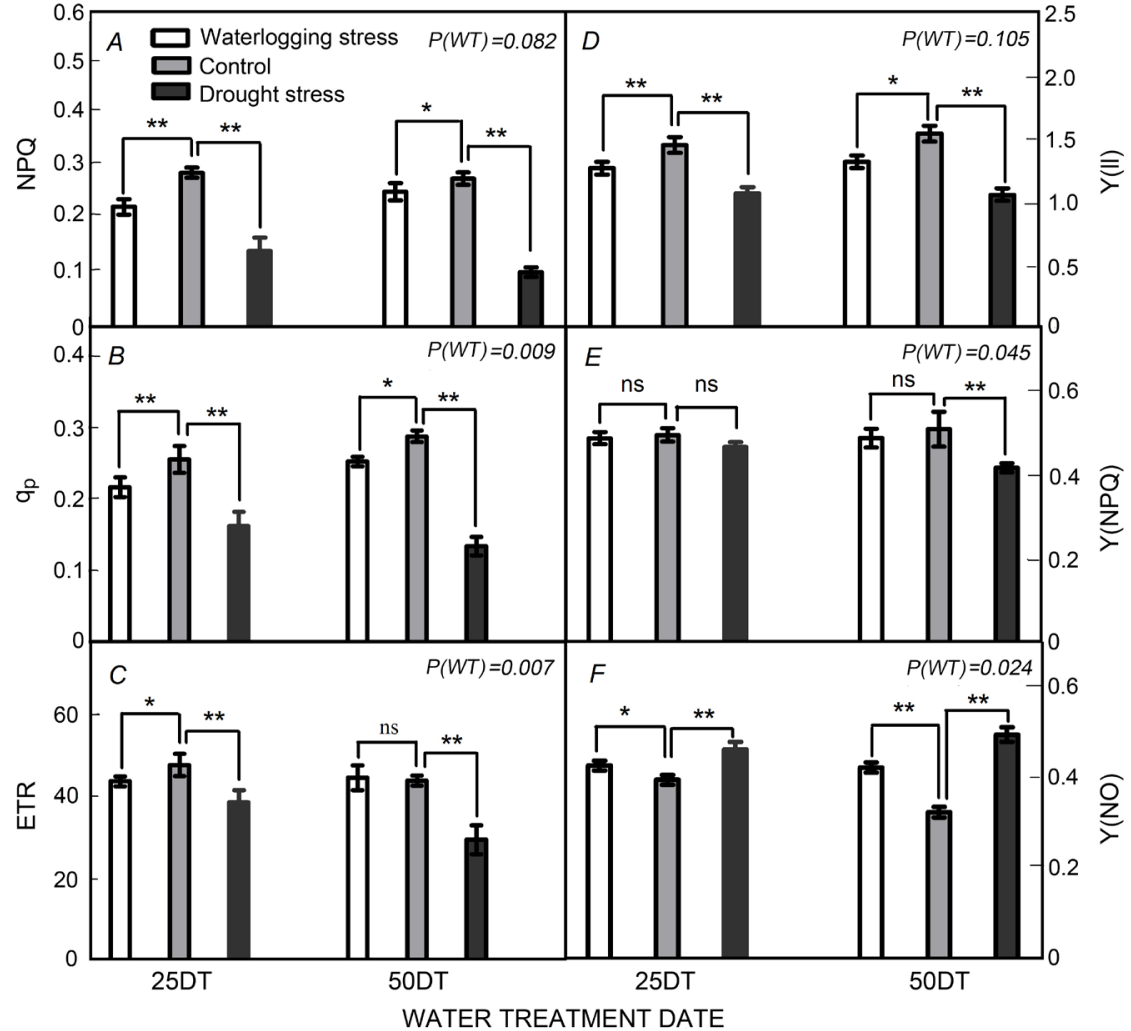

Fig. 3. Changes in chlorophyll fluorescence in the leaves of sorghum under water stress applied at 25 and $50 \mathrm{~d}$ after sowing. Data represent means $\pm \mathrm{SD}, n=5$. $^{* *}$ - significant difference at the 0.01 level, ${ }^{*}$ - significant difference at the 0.05 level, ns - difference is not significant. ETR - electron transfer rate, NPQ - nonphotochemical quenching, $\mathrm{Y}_{(\mathrm{NO})}$ - nonregulated energy dissipation of electron yield, $Y_{(\mathrm{NPQ})}$ - quantum energy output under light adaptation, DT - days after treatment, WT - water treatment, $P(\mathrm{WT})$ - significant difference in water treatments. this study, leaf Chl $a$ content significantly declined during water stress. This finding is basically consistent with the previous report that $\mathrm{Chl}$ in crops decreases under drought or EM stress, and that this decrease is mainly due to damage to the chloroplasts (Bai et al. 2008). Moreover, it has been pointed out that when sorghum is subjected to water stress, the absorption of excess light energy by the leaves, which causes damage to the photosynthetic apparatus, could be avoided by reducing the $\mathrm{Chl}$ content, especially $\mathrm{Chl} a$ content (Guan and $\mathrm{Gu}$ 2009). This hypothesis has been confirmed in wheat (Tambussi et al. 2005), and the results of this study suggest that this physiological regulatory mechanism likely operates in sorghum plants subjected to water stress.

Crop production and water consumption are coupled with crop light capture and transpiration (Wullschleger and Oosterhuis 1991). Leaf photosynthesis is the basis of plant growth and development, and photosynthetic rate is an important indicator of plant biological and economic yield (Zlatev and Yordanov 2004). The results of this study found that $P_{\mathrm{N}}$ decreased under water stress, accompanied by decreases in photosynthetic parameters, such as $g_{\mathrm{s}}$ and $E$, which is a well-known phenomenon (Tang et al. 2002). However, some studies also showed that photosynthesis may be controlled by the capacity of the chloroplast to fix $\mathrm{CO}_{2}$ rather than by increased diffusive resistance under severe water stress (Wullschleger and Oosterhuis 1991). There are also reports showing that the effects of drought and excessive water stress on photosynthesis are often not caused by stomatal factors, but by nonstomatal factors (Redondo-Gómez et al. 2010). The reason for the differences between findings of our study and others may be due to differences in the duration and intensity of water stress and crops studied.

One very interesting phenomenon found in this study is that sorghum leaf LSP and LCP decreased under drought or excessive water stress. It has been reported that crop photosynthetic production is closely related to leaf LSP and LCP (Peri et al. 2011). In this study, we also found that there was a relatively small decline in LSP under water stress, indicating that sorghum has a good self-regulation ability in photosynthesis. Hymus et al. (2002) reached similar conclusions.

Chl fluorescence kinetics reflects the intrinsic properties of photosynthetic systems and can be used to detect the effects of stress on photosynthesis (Raines 2011, Ashraf and Harris 2013). The photosynthetic kinetics of plants has become a research hot spot, and kinetics parameters have been widely used in water stress physiology research (Dannehl et al. 1996, Elsheery and Cao 2008). In this study, Chl fluorescence kinetics was used to analyze sorghum pairs. At present, it is believed that water stress can affect the $\mathrm{F}_{0}, \mathrm{~F}_{\mathrm{m}}$, and $\mathrm{F}_{\mathrm{v}}$ of plant leaves (Kalaji et al. 2016). In this study, although $F_{0}$ and $F_{v}$ increased, $F_{m}$ did not change significantly. The reason, why $F_{m}$ did not change significantly in response to stress, may be that the degree of water stress was not high enough to severely damage the leaves or alter metabolic pathways in sorghum. In addition, this study also found that leaf $F_{v} / F_{m}$ decreased, which is consistent with the previous finding that water stress can reduce $F_{v} / F_{m}$, and that changes in this ratio can be used to indicate crop resistance or tolerance to drought (Raines 2011). The results are consistent with those of other studies (Murata et al. 2007). Our finding 
further demonstrates that the leaf $\mathrm{F}_{\mathrm{v}} / \mathrm{F}_{\mathrm{m}}$ can be used as an important index to evaluate the resistance of sorghum to water stress.

It has been reported that increased $\mathrm{q}_{\mathrm{P}}$ could dissipate excitation energy at the expense of photochemical utilization (Ren et al. 2007). This study found that $\mathrm{q}_{\mathrm{p}}$ decreased significantly under water stress, which is similar to the findings of Yin et al. (2006), but others found that $\mathrm{q}_{\mathrm{p}}$ was only slightly reduced under water stress (Murata et al. 2007). These different observations are likely due to the different test materials used. However, differences in the water stress treatments and stress levels are also likely to be important. The present study also found that ETR and $\mathrm{Y}_{\text {(II) }}$ were lower after water stress than that under normal conditions, indicating that water stress reduced the actual photosynthetic capacity. This is basically consistent with the previous report that NPQ increased and ETR decreased in Rhamnus ludovicis-alvatoris and other Mediterranean tree species during water stress (Kato et al. 2003).

Conclusions: In general, during the critical growth period of sorghum, from the growing point differentiation to the half-bloom growth stages, water deficit has a greater impact on the growth of sorghum than excessive water. Water stress can lead to a significant decrease in Chl $a$ content in the leaves of sorghum, which in turn affects photosynthesis and parameters such as $g_{\text {s }}$ and $E$. These changes are accompanied by a decrease in the LCP and LSP of the blade and by changes in chlorophyll fluorescence, and improve the resistance of sorghum to drought and waterlogging stress.

\section{References}

Abid M., Ali S., Qi L.K. et al.: Physiological and biochemical changes during drought and recovery periods at tillering and jointing stages in wheat (Triticum aestivum L.). - Sci. Rep.-UK 8: 4615, 2018.

Ashraf M., Harris P.J.C.: Photosynthesis under stressful environments: An overview. - Photosynthetica 51: 163-190, 2013.

Bai J., Xu D.H., Kang H.M. et al.: Photoprotective function of photorespiration in Reaumuria soongorica during different levels of drought stress in natural high irradiance. Photosynthetica 46: 232-237, 2008.

Dannehl H., Wietoska H., Heckmann H., Godde D.: Change in D-protein turnover and recovery of photosystem II activity precede accumulation of chlorophyll in plants after release from mineral stress. - Planta 199: 34-42, 1996.

Downie A., Miyazaki S., Bohnert H. et al.: Expression profiling of the response of Arabidopsis thaliana to methanol stimulation.Phytochemistry 65: 2305-2316, 2004.

Elsheery N.I., Cao K.F.: Gas exchange, chlorophyll fluorescence, and osmotic adjustment in two mango cultivars under drought stress. - Acta Physiol. Plant. 30: 769-777, 2008.

Gomes-Laranjo J., Coutinho J.P., Galhano V., Cordeiro V.: Responses offive almond cultivars to irrigation: Photosynthesis and leaf water potential. - Agr. Water Manage. 83: 261-265, 2006.

Guan X., Gu S.: Photorespiration and photoprotection of grapevine (Vitis vinifera L. cv. Cabernet Sauvignon) under water stress. - Photosynthetica 47: 437-444, 2009.
Guo Y.Y., Yu H.Y., Yang M.M. et al.: Effect of drought stress on lipid peroxidation, osmotic adjustment and antioxidant enzyme activity of leaves and roots of Lycium ruthenicum Murr. seedling. - Russ. J. Plant Physl+ 65: 244-250, 2018.

Houx J.H., Fritschi F.B.: Influence of midsummer planting dates on ethanol production potential of sweet sorghum. Agron. J. 105: 1761-1768, 2013.

Hymus G.J., Snead T.G., Johnson D.P.: Acclimation of photosynthesis and respiration to elevated atmospheric $\mathrm{CO}_{2}$ in two Scrub Oaks. - Glob. Change Biol. 8: 317-328, 2002.

Kadam S., Abril A., Dhanapal A.P. et al.: Characterization and regulation of aquaporin genes of sorghum [Sorghum bicolor (L.) Moench] in response to waterlogging stress. - Front. Plant Sci. 8: 862-869, 2017.

Kalaji H.M., Jajoo A., Oukarroum A. et al.: Chlorophyll $a$ fluorescence as a tool to monitor physiological status of plants under abiotic stress conditions. - Acta Physiol. Plant. 38: 102, 2016.

Kataria S., Baghel L., Guruprasad K.N.: Effect of seed pretreatment by magnetic field on the sensitivity of maize seedlings to ambient ultraviolet radiation (280-400 nm). - Int. J. Trop. Agric. 33: 3645-3652, 2015.

Kato M.C., Hikosaka K., Hirotsu N. et al.: The excess light energy that is neither utilized in photosynthesis nor dissipated by photoprotective mechanisms determines the rate of photoinactivation in photosystem II. - Plant Cell Physiol. 44: 318-325, 2003.

Khan M.S.A., Karim M.A., Haque M.M. et al.: Influence of salt and water stress on growth and yield of soybean genotypes. Trop. Agric. Sci. 39: 167-180, 2016.

Li L., Wang F., Yan P. et al.: A phosphoinositide-specific phospholipase $\mathrm{C}$ pathway elicits stress-induced $\mathrm{Ca}^{2+}$ signals and confers salt tolerance to rice. - New Phytol. 214: 1172$1187,2017$.

Liu R.X., Chen B.L., Wang Y.H. et al.: [Effects of nitrogen on cotton root growth under drought stress and after watering during flowering and boll-forming stages.] - Chin. J. Plant Ecol. 33: 405-413, 2009. [In Chinese]

Murata N., Takahashi S., Nishiyama Y., Allakhverdiev S.I.: Photoinhibition of photosystem II under environmental stress. BBA-Bioenergetics 1767: 414-421, 2007.

O'Shaughnessy S.A., Evett S.R., Colaizzi P.D., Howell T.A.: A crop water stress index and time threshold for automatic irrigation scheduling of grain sorghum. - Agr. Water Manage. 107: 122-132, 2012.

Peri P.L., Arena M.E., Martínez Pastur G.J., Lencinas M.V.. et al.: Photosynthetic response to different light intensities, water status and leaf age of two Berberis species (Berberidaceae) of Patagonian steppe, Argentina. - J. Arid. Environ. 75: 12181222, 2011.

Radhakrishnan R., Leelapriya T., Kumari B.D.: Effects of pulsed magnetic field treatment of soybean seeds on calli growth, cell damage and biochemical changes under salt stress. Bioelectromagnetics 33: 670-681, 2012.

Rahbarian R., Khavari-Nejad R., Ganjeali A. et al.: Drought stress effects on photosynthesis, chlorophyll fluorescence and water relations in tolerant and susceptible chickpea (Cicer arietinum L.) genotypes. - Acta. Biol. Cracov. Bot. 53: 4756, 2011.

Raines C.A.: Increasing photosynthetic carbon assimilation in $\mathrm{C}_{3}$ plant to improve crop yield: Current and future strategies. Plant Physiol. 155: 36-42, 2011.

Redondo-Gómez S., Mateos-Naranjo E., Moreno F.J.: Physiological characterization of photosynthesis, chloroplast ultrastructure, and nutrient content in bracts and rosette leaves from Glaucium flavum. - Photosynthetica 48: 488-493, 2010. 
Ren J., Dai W.R., Xuan Z.Y. et al.: The effect of drought and enhanced UV-B radiation on the growth and physiological traits of two contrasting poplar species. - Forest Ecol. Manag. 239: 112-119, 2007.

Shao R.X., Xin L.F., Zheng H.F. et al.: Changes in chloroplast ultrastructure in leaves of drought-stressed maize inbred lines. - Photosynthetica 54: 74-80, 2016.

Sun Y.Y., Sun Y.J., Wang M.T. et al.: [Effects of seed priming on germination and seedling growth under water stress in rice.] Acta Agron. Sin. 36: 1931-1940, 2010. [In Chinese]

Tambussi E.A., Nogués S., Araus J.L.: Ear of durum wheat under water stress: water relations and photosynthetic metabolism. Planta 221: 446-458, 2005.

Tang A.C., Kawamitsu Y., Kanechi M., Boyer J.S.: Photosynthetic oxygen evolution at low water potential in leaf discs lacking an epidermis. - Ann. Bot.-London 89: 861-870, 2002.

Ullah A., Manghwar H., Shaban M. et al.: Phytohormones enhanced drought tolerance in plants: A coping strategy. Environ. Sci. Pollut. R. 25: 33103-33118, 2018.

Vandoorne B., Mathieu A.S., Van den Ende W. et al.: Water stress drastically reduces root growth and inulin yield in Cichorium intybus (var. sativum) independently of photosynthesis. J. Exp. Bot. 63: 4359-4373, 2012.

Viator S., Alison W., Harrell D. et al.: Production of Sweet Sorghum in Louisiana as a Biofuel Feedstock Crop. Louisiana State University Agricultural Center, Baton Rouge 2010.

Wang C., Isoda A., Wang P.: Growth and yield performance of some cotton cultivars in Xinjiang, China, an arid area with short growing period. - J. Agron. Crop Sci. 190: 177-183, 2004.

Wang X., Shi Y., Wang Q., Li Y.: Dorsoventral regulation of photosynthetic functions related to morphological and anatomical structures in field-grown sorghum. - Photosynthetica 57: 607-616, 2019b.

Wang Y.W., Jiang D.X., Hou J.J., Chen G.X.: Physiological characterization and thylakoid ultrastructure analysis in super high-yield hybrid rice leaves under drought stress. Photosynthetica 57: 890-896, 2019a.

Waraich E.A., Ahmad R., Ashraf M.Y. et al.: Improving agricultural water use efficiency by nutrient management in crop plants. - Acta Agr. Scand. B-S. P. 61: 291-304, 2011.

Wullschleger S.D., Oosterhuis D.M.: Photosynthesis, transpiration, and water-use efficiency of cotton leaves and fruit. Photosynthetica 25: 505-515, 1991.

$\mathrm{Xu}$ C.X., Lv Y., Chen C.F. et al:: Blue light-dependent phosphorylations of cryptochromes are affected by magnetic fields in Arabidopsis. - Adv. Space Res. 53: 1118-1124, 2014b.

$\mathrm{Xu}$ W., Ji S.: [Application of DPS data processing system in biostatistical analysis.] - J. Shandong Agr. Univ. 24: 24-27, 2014a. [In Chinese]

Yin C.Y., Berninger F., Li C.Y.: Photosynthetic responses of Populus przewalski subjected to drought stress. Photosynthetica 44: 62-68, 2006.

Zaidi P.H., Rafique S., Singh N.N.: Response of maize (Zea mays L.) genotypes to excess soil moisture stress: Morphophysiological effects and basis of tolerance. - Eur. J. Agron. 19: 383-399, 2003.

Zhang X.Z.: [Crop Physiology Research Method.] Pp. 38-45. China Agricultural Press, Beijing 1992. [In Chinese]

Zhou Y.F., Wang D.Q., Lu Z.B. et al.: [Effects of drought stress on photosynthetic characteristics and endogenous hormone ABA and CTK contents of green sorghum.] - Sci. Agr. Sin. 47: 655-663, 2014. [In Chinese]

Zlatev Z.S., Yordanov I.T.: Effects of soil drought on photosynthesis and chlorophyll fluorescence in bean plants. Bulg. J. Plant Physiol. 30: 3-18, 2004.

Zou J.N., Jin X.J., Zhang Y.X. et al.: Effects of melatonin on photosynthesis and soybean seed growth during grain filling under drought stress. - Photosynthetica 57: 512-520, 2019.

(C) The authors. This is an open access article distributed under the terms of the Creative Commons BY-NC-ND Licence. 